Battakhov P.P. ${ }^{\odot}$

Candidate of Law Sciences, senior research associate of the sector of enterprise and corporate law of Institute of state and law of the Russian Academy of Sciences (IGP RAS)

\title{
FEATURES OF LEGAL REGULATION OF TRANSFER OF ENTERPRISES TO THE CIVIL CODE OF THE RUSSIAN FEDERATION
}

\begin{abstract}
The article considers the study of the turnover of an enterprise in the civil code, which is carried out in this work, will disclose the features of the legal regulation of transactions with enterprises when they are leased or management is transferred to a trustee. The enterprise is considered as a property complex and acts as an independent object of economic activity.
\end{abstract}

Keywords: enterprise, property complex, lease, trust management, state registration, heir, testator.

The enterprise, according to the Civil Code of the Russian Federation, is a legal entity. It refers to the combination of property that is used to conduct business. On this side, the company is a component of real estate objects. It should be noted that the Project for making changes and additions to the Civil Code of the Russian Federation provides for the exclusion of the enterprise from the composition of real estate. It is assumed that it should be attributed to the objects of property complexes.

As an object of law, a company is the object of contracts of ongoing transactions, in particular, purchase or sale, leasing, transfer of control to a trustee and other transactions of a civil nature.

An enterprise is a property complex consisting of a combination of property of all types that are used in the process of work. It is necessary to carry buildings to them, constructions, grounds, stock, the equipment and also raw materials and finished goods Debts and the rights of the requirement of the company are also her property. In addition, the company should take into account such property as its exclusive rights to a corporate name, formation of a commercial nature, a service mark, etc.

When contractual arrangements are made for the lease of a company that is the object of the right and the aggregate of all types of property, the lessor undertakes to provide the lessee with working capital for temporary use or possession on a paid basis. The contract applies to land, buildings and structures, equipment, finished products, raw materials, fuel, etc. When the parties enter into a lease agreement, the document can provide for conditions as to how certain rights will be transferred, for example, to the use of land, water and other natural resources, buildings, structures, equipment. Also, the parties may come to an agreement on other property rights that have a connection with the enterprise, granting exclusive rights to property objects.

It should be emphasized that individual elements of a building or structure that are used for different purposes, for example, to place advertising products on them, cannot be attributed to rental relationships.

Transfer by the lessor of its own right to conduct a certain type of activity based on obtaining a license to conduct a specific activity. If the tenant plans to continue working in the same direction, he needs to obtain his license for this type of activity.

According to Russian laws, when leases are concluded, as in the sale of an enterprise, it must undergo the procedure of state registration, otherwise they will be invalid. At the same time, the legislator does not pay attention to the rights that apply to objects of industrial property that must undergo state registration. This may lead to a situation where the lease agreement of the enterprise is concluded, executed, but the question remains about the need to undergo state

\footnotetext{
${ }^{\circ}$ Battakhov P.P., 2020
} 
registration of granting exclusive rights to objects of industrial value that are part of the enterprise. In addition, the legislator also does not establish additional requirements for registering exclusive rights separately from the transaction. This may lead to a misunderstanding on the part of other potential counterparties of the rights holder.

In our opinion, the legislator needs to pay attention to this inaccuracy in the existing laws. To do this, it is necessary to establish a specific requirement: if an enterprise that is a property complex has an exclusive right to an object of industrial property that has passed the registration procedure (the grounds may be legal or voluntary), this agreement must undergo state registration, as well as registration in Rospatent, which is a federal executive body in terms of intellectual property.

In order to legally transfer the right to manage the company to a trustee, there are different grounds. One of them is the death of the inheritor of rights, the inheritance of which contained the enterprise. To protect the rights of heirs, recipients of waivers and other interested persons in inheritance rights, measures are required to protect the property received in the inheritance, as well as to manage the name. Measures to preserve the enterprise should be aimed at preserving the property, the management of which is transferred to a trustee. Such measures are needed so that the transferred property remains and works smoothly, and its activities are profitable, because this is the value of the enterprise from an economic point of view.

It should be emphasized that the process when the right to manage a company is transferred to a trustee is not sufficiently described in legal sources. In accordance with the first paragraph of Article 1012 of the Civil Code of the Russian Federation, the founder of the company, which is one party to the contractual relations, transfers property to the trustee who will manage it, as the other party to the contract. The transfer of rights is carried out for the period specified in the concluded contract. At the same time, the recipient of the rights must be obliged to administer the specified property, comply with the interests of the founder of the company or the person whom he indicated, who in this case are the recipients of the benefit.

Different authors in legal sources distinguish different reasons for a trustee to begin to manage property, the company is no exception. These bases with a fairly complex composition. So, according to Z.E. Benevolensky, the transaction is the basis for the emergence of legal relations, as a result of the management of the company by a trustee. For example, the execution of a transaction is possible as a contract or a will, it also indicates other circumstances provided for by current law[1]. 1. According to V.V. Chubarov, these legal relations arise in the presence of a will or contract of the executor of the will, which is executed with a person exercising trust. Here it is necessary to dwell in more detail on the legal facts that V.V. Vitryansky highlighted: agreements concluded between the parties to the agreement; direct transfer of property as the object of legal relations; state registration of the process of transferring property management to a trustee; grounds, according to the current legislation[3].

We agree with such a composition. We believe that for the relationship of trust to arise, the legal basis and the transaction itself are required. If real estate objects are transferred to trust, the additional basis is a transaction that is provided for by the law on state registration. In view of the fact that at the legislative level it is provided that this transaction is executed by contract, the direct transfer of property is one of the grounds.

The issue remains that the contract to transfer control to a proxy is binding on the parties. N. Ostapyuk put forward a proposal to consider such grounds mandatory when the management of property is transferred to a trustee[4].

- The inheritance received is not accepted by the heirs;

- There are no heirs in the location of the property entitled to it;

- The guardian has not taken possession of the inheritance when the direct heir is not yet capable.

Many scholars agree that it is the responsibility of the parties to the contract to trust the company. The wording of article 1173 of the Civil Code of the Russian Federation became the basis to come to this conclusion[5]. 
According to M.V. Telyukina, when an agreement is concluded to transfer the management of the company to a trustee, the parties to the relationship do not have this obligation[6]. V.V. Vitryansky believes that the conclusion of this agreement is possible, according to the rules prescribed in Article 445 of the Civil Code of the Russian Federation, which states that this is a prerequisite when the parties formalize contractual relations[3]. We agree with this position in view of the fact that the rule of current law determines the obligation of the parties to enter into contractual relations. If we consider article 1026 of the Civil Code of the Russian Federation, then it is said that when the transfer of property management to a trustee is carried out legally, the parties can conclude this agreement on this, but this is not a prerequisite. "Trust property may also be established."

If a person authorized for notarial actions does not have to conclude agreements on the transfer of property to the trust office, respectively, he is not responsible for the damage to the company, the reason for which will be simple to work. In cases where there is an owner or title owner of the company that manages the work, it is not advisable to transfer it to the trustee. However, if the entity that manages the enterprise is absent in order to preserve its property, as well as the enterprise itself for its further work, it is the responsibility of the notary to take all measures to preserve and manage the company's property, according to the statement of interested persons. But for the management of the company to be transferred to a trustee, the founder requires the consent of the owner. If there is no such consent, it is impossible to form a contractual relationship, just as in cases where the trustee already manages the enterprise, a third person received a legal right of ownership.

Different authors of legal literature express a different opinion as to what legal status should be possessed by the person who manages the company on the basis of the contract. According to L.G. Efimova, a commercial bank can manage hereditary property, because its duties include collecting and ensuring the safety of all assets of the inheritance, paying taxes, dividing property, as well as providing personal services to family members[7]. According to O.E. Romanov, it is necessary that the person who will exercise trust management be a qualified specialist. This is the only way to ensure stable and profitable work of the company[8]. We believe that when the right to manage a company is transferred to a trustee, the property should not only function qualitatively, but also multiply in number. Judicial practice defines this objective as basic.

The process of state registration of contractual relations is the issue in the legal regulation of transfer to the trust management of the enterprise, which today in this direction has the most problems. In cases where it is decided to transfer the management of the company to a trustee, events can develop in two options. In the first case, the inheritance will register ownership of the company. If we talk about concluding a contract in order to transfer the management of the company to a trustee, this fact is an encumbrance of real estate, accordingly it is subject to registration with public authorities. However, there are contradictions with the second paragraph of article 13 of Federal Law No. 122-Ф3 "On state registration of rights to real estate and transactions with it[9]."

It should be stated that state registration of restrictions on property rights and other rights of a physical nature, encumbrance of real estate objects is possible only on the initiative of the recipient of the right or if the person has such a right. When registration is carried out by a person who does not have the required rights, rules 16 of the article of this Federal Law must be respected. Specifically, the owner of the rights must be notified that a restriction or encumbrance has been registered. It becomes obvious that the owner of the company died, respectively, it is impossible to notify him of the fact of state registration. It turns out that the established rule cannot be fulfilled in any way.

The second option is the absence of state registration of ownership. When registering an agreement on the transfer of property management to a trustee, a number of difficulties are also possible. The fact is that the company in this case is its property in the complex, and its 
registration with state bodies is carried out only in order to conduct transactions with it (sell, rent, etc.)[10].

When transferring an enterprise to the management, which is part of the property received by inheritance, the term is limited to 6 months (until the heirs acquire ownership of this property). This distinguishes from the general rules. Given the fact that the contract has a short validity period, as well as the duration of the state registration process, it makes no sense to transfer the enterprise to trust.

Analyzing the legal literature, it can be seen that the authors propose to solve this problem by replacing the legislative requirement for state registration of an agreement on the transfer of hereditary property to trust for compulsory certification by a notary. According to E.A. Khodyreva, this proposal does not conflict with the legislation in force at the moment, meets the requirements specified in the second paragraph of Article 1026 of the Civil Code of the Russian Federation, according to which, based on the essence of the emerging relationship, it is provided that for trust management on the grounds established at the legislative level, it is possible to apply the general rules for transferring management to a proxy. Also, E.A. Khodyreva notes that if the notary certified the agreement on the transfer of management of the company to a trustee, the procedure for transferring property would become much easier and faster. This would ensure the qualitative protection of the rights and legitimate interests of inherited persons[11].

But further, E.A. Khodyrev noted that the proposed solution to the problem conflicts with the unified system of state registration of real estate objects, transactions in which they are objects.

Thus, we consider it advisable to introduce into the Federal Law No. 122-Ф3 "On State Registration of Rights to Real Estate and Transactions with It" a number of important additions and changes. First of all, the requirement that the transfer of control of the company to a trustee when the owner has died requires approval should be excluded. It is also necessary to supplement this legislative document with a number of special provisions that will limit the term of the contract when an enterprise included in the hereditary property is transferred to trust. In addition, we consider it necessary to provide for a simplified procedure for registering contracts of this type.

\section{References:}

1. Benevolen Z.E. Trust management of property in the field of entrepreneurship. St. Petersburg, 2002. C. 104.

2. Commentary to the Civil Code of the Russian Federation, part two (article by article). 2nd ed ./Hand. aut. call. and otv. ed. O.N. Sadikov. M., 1997.

3. Vitryansky V.V. Trust Management Agreement. M., 2001. C. 49 and 105.

4. Ostapyuk N. Measures to protect hereditary property//Legality. 2003. № 12. S. 49 - 52.

5. Begichev A.V. Inheritance according to the law of the enterprise as a property complex in the Russian Federation: Dis.... edging. юрид. sciences. C. 119; Vlasov Yu.N., Kalinin V.V. Notary: Lecture course. M., 2002. C. 313; Guev A.N. Post-article commentary on Part Three of the Civil Code of the Russian Federation. M., 2002. P 225.

6. Telyukina M.V. Hereditary Law: Commentary of the Civil Code of the Russian Federation: Study. grant. S. 170, 171.

7. Efimova L.G. Banking transactions: law and practice. M., 2001. S. 614 - 615.

8. Romanov O.E. Enterprise and other property complexes as objects of civil rights: Autoref. dis.... edging. юрид. sciences. C. 10.

9. Federal Law of 21.07.1997 No. 122-Ф3 "On State Registration of Rights to Real Estate and Transactions with It "//Collection of Legislation of the Russian Federation, 28.07.1997, No. 30, Art. 3594.

10. Rules for entering records of rights to an enterprise as a property complex and transactions with it into the Unified State Register of Rights to Real Estate and Transactions with It and 
Interaction between the Federal Registration Service and its Territorial Organizations. By order of the Ministry of Justice of Russia dated 04.03.2005 No. 16//Rossiyskaya Gazeta, No. 56, 22.03.2005.

11. Khodyreva E.A. Enterprise as an object of hereditary succession. M.: Norma, Infra-M, 2010. 